\title{
Strategic Communication for Security \& National Defense: Proposal for an Interdisciplinary Approach
}

\author{
Cristian E. Guerrero-Castro * \\ $\sum \begin{aligned} & S+S D=(S P . m+I N P+N I)=\left(S^{*}\right)+ \\ & C+S D=(I n f . I n t, D e c l, C o d l, S i g l, P l t\end{aligned}$ \\ $C+S D=(\operatorname{Inf}$, Int,Dec1,Cod1,Sig1,Plt,Dif $)=\left(C^{*}\right)+[I S$, Sec,Def] $=$ S.C.S.N.D
}

\section{Introduction}

Most recent military actions have provided stark examples of the increasing power of communications in the public and governmental arena regarding the role that direct actors play in disputes characterized as "conflicts of interests." These examples have also shown how communications can directly influence perceptions within the international system and among those who enjoy "freedom of action," who are always pursued by an arsenal of immediate media technology. However, in a conflict of interests, nation-states act along political lines and use the tools of the "fields of action" (internal, external, economic, and defense) to execute their national strategies, with the objective of maintaining or pursuing political and strategic objectives. But how can we defend ourselves against communications, or use them to benefit our political-strategic interests?

After the terrorist attacks of September 2001, three capabilities concerning communication began to develop within the George W. Bush Administration in the U.S.: "Information Operations and Psychological Operations" (IO and PSYOPS); "Public Affairs" (PA); and "Defense Support to Public Diplomacy" (DSPD). This was done by dedicating integrated communications technologies for use in pursuing specific tactics, operations, and other elements of the national strategy in this so-called "war of perceptions," with the objective of achieving credibility and thus freedom of action. In that moment the concept of "strategic communication" started to appear in the vocabulary of many people linked to security and national defense issues.

Between 2002 and 2004, after many reports, studies, and drafts of the definition of strategic communication in the area of defense, the concept migrated to other areas such as business, public relations, and social communication, generating dissonance

* Cristian E. Guerrero-Castro holds a Licentiate in Social Communication and a Master's in Strategic Communication; he graduated from the National Academy of Political and Strategic Studies at the Ministry of Defense in Chile with a post-graduate degree in Political and Strategic Studies and a Master's in Security and Defense. He graduated from the CHDS at the National Defense University of USA with the specialty of "Strategy and Defense Policy." In 2013, he participated in the "CBR-Nuclear Defense Course" at the NATO School in Germany. He is currently working as researcher and acting managing editor of the PTSS at the George C. Marshall European Center for Security Studies in Garmisch-Partenkirchen, Germany. 


\title{
THE QUARTERLY JOURNAL
}

within the concept. Meanwhile, another concept, called "strategic communications" (the only difference being the "s") was born, causing even more confusion.

This article intends to offer an interdisciplinary approach to strategy and mass communication in the field of security and national defense and to define, by means of hermeneutical, qualitative, and quantitative research techniques, the definitions, missions and lineaments of strategic communication. It will create a model proposal for "Strategic Communication for Security and National Defense," with the objective of tracing the guidelines of this vital tool for pursuing and maintaining permanent national objectives, including peacekeeping. We will begin with a look at this concept, its evolution and attempts of definitions in recent years.

\section{The Evolution of the Definition of Strategic Communication}

The Report of the Defense Science Board Task Force on Strategic Communication in the year 2004 defined strategic communication as follows:

\begin{abstract}
Strategic communication is a vital component of U.S. national security. It is in crisis, and it must be transformed with a strength of purpose that matches our commitment to diplomacy, defense, intelligence, law enforcement, and homeland security. Presidential leadership and the bipartisan political will of Congress are essential. Collaboration between government and the private sector on an unprecedented scale is imperative. ... Moreover, strategic communication efforts must reinforce key themes and messages and constantly be measured against defined objectives. As a result, adjustments must be made and those responsible for implementation held accountable. ${ }^{1}$
\end{abstract}

This shows that strategic communication "efforts" are a vital component of U.S. national security.

Moreover, in 2005 the Director of Strategic Communications and Information at the National Security Council (NSC), Jeff Jones, pointed out the importance of strategic communication by saying: "There is little evidence of cooperation, coordination, or even more, the appreciation of the impact of strategic communication." 2

Then, at the end of 2006, after a visit to the Pentagon with a delegation of the ANEPE, I read another definition of strategic communication in the "QDR Execution Roadmap for Strategic Communication 2006" that defines strategic communication as communication that "focuses United States Government process and efforts to understand and engage key audiences to create, strengthen, or preserve conditions favorable to advance national interests and objectives through the use of coordinated information, themes, plans, programs, and actions synchronized with other elements of national

1 U.S. Department of Defense, Office of the Under Secretary for Acquisition, Technology, and Logistics, "Report of the Defense Science Board Task Force on Strategic Communication," (Washington, D.C., September 2004); available at http://www.acq.osd.mil/dsb/reports/ ADA428770.pdf.

2 Jeffrey B. Jones, "Strategic Communication: A Mandate for the United States," Joint Force Quarterly 39 (October 2005). 
power." ${ }^{3}$ This provides additional evidence for the fact that strategic communication can be used in pursuit of national interests using the coordination of information, which I refer to as "logic of action." It also clarifies that this coordinated information must be synchronized with other elements of national power.

Subsequently, the National Defense Authorization Act of 2009 called for the creation of a new area for strategic communication. The House Armed Services Committee pointed out its critical importance by saying: "The committee believes the Department should leverage these efforts to designate a science and technology thrust area for strategic communication and focus on critical science and technology opportunities...." 4

Considering the impact of strategic communication, many professionals borrow this concept irresponsibly and create differing definitions and roles for it, attempting to integrate it into many different areas, causing confusion with the result that each public or government entity develops a "strategic communication" plan according to the interpretation of whoever is in charge. Often these efforts are simply carrying out social communication, or even marketing, which is often confusing, or wrong. So, the following questions have emerged:

- What is strategic communication?

- What is strategic communication for security and national defense?

- When is communication strategic?

Later, in 2010, the White House Strategic Communications Report to Congress declared:

Over the last few years, the term "strategic communication" has become increasingly popular. However, different uses of the term "strategic communication" have led to significant confusion. As a result, we believe it is necessary to begin this report by clarifying what we mean by strategic communication. By "strategic communication(s)" we refer to: (a) the synchronization of words and deeds and how they will be perceived by selected audiences, as well as (b) programs and activities deliberately aimed at communicating and engaging with intended audiences, including those implemented by public affairs, public diplomacy, and information operations professionals. ${ }^{5}$

After many years of confusion, last year, the National Defense Authorization Act of 2012 changed the concept of strategic communication that they mentioned before to strategic communications by declaring: "The committee continues to support information operations (IO) and strategic communications (SC) as important tools for coun-

3 U.S. Department of Defense, "Quadrennial Defense Review_Execution Roadmap for Strategic Communication 2006," (Washington, D.C., September 2006); available at www.dtic.mil/dtic/tr/fulltext/u2/a495367.pdf.

4 U.S. House of Representatives Armed Services Committee, "Report on H.R. 5658 [the National Defense Authorization Act for Fiscal 2009]," (Washington, D.C., 16 May 2008); available at www.dtic.mil/congressional_budget/pdfs/FY2009_pdfs/HASC_110-652.pdf.

5 White House Strategic Communications Report to Congress, Released March 17, 2010. 


\section{THE QUARTERLY JOURNAL}

tering enemy narratives, as well as engaging with the global community." 6 Therefore, strategic communication is seen as something that should be used in support of national interests and synchronized with national power.

\section{The Problems}

At this point, we have a general idea about the subject and goals of this article, but to understand the phenomenon of study we must first delve into the current qualitative problems concerning the confusion that exists about the definition of strategic communication.

\section{Strategic Communication?}

In the post-9/11 era, strategic communication has become a term used for more than a hundred disciplines, pseudo-disciplines, and professions. It is deployed as a recurrent and helpful concept to indicate that a project involves smart thinking, planning, and coordination, and is ruthlessly used for marketing, business, public relations, and many other areas. But does strategic communication mean the same thing in these various fields? How can those areas develop strategic communication? Does the concept even make sense in all these areas?

So what happens when we try to speak of strategic communication in the area of security and national defense? Are we referring to public relations, journalism, diplomacy, military diplomacy, telecommunications, propaganda, or efforts to shape a country's image? Perhaps it relates to the coordination of internal and external communications of public, state, and government institutions? Or it is simply government marketing? What happens when the nation must act or react to a scenario where communications are vital to support permanent national objectives? What kind of strategic communication should be used, and according to the definition of which profession should it be executed? As was noted above, each government, ministry, department, institution, or entity develops its own approach to strategic communication, defined by the professional who is in charge, which results in the confusing proliferation of the application of the term to situations where it is not appropriate. As Professor Rosa Brooks correctly notes, "[There is] no question in my mind there are people in the name of U.S. government strategic communications doing stupid things right this minute." 7

6 Report of the House Armed Services Committee on the National Defense Authorization Act for Fiscal Year, 2012.

7 "Ten Years On: The Evolution of Strategic Communication and Information Operations since 9/11: Hearing before the Subcommittee on Emerging Threats and Capabilities of the Committee on Armed Services House of Representatives," 112 Cong. (H.A.S.C. No. 112-49, 12 July 2011); available at http://www.gpo.gov/fdsys/pkg/CHRG-112hhrg67796/pdf/CHRG112hhrg67796.pdf. 


\section{Strategic Communication or Social Communication?}

Let me include a personal experience in relation to the previous question. In 2006 during a visit to Washington D.C., I had the opportunity to meet with two professionals involved in the use of communications in the area of security and national defense. They were a journalist in charge of the internal and external communications of a government agency, and an official of the General Staff in charge of command communications. When I asked them what was the mission of communications in the area of security and national defense, the journalist immediately said that it was not just communication, but it was "strategic communication," and that the mission was to integrate the broader society with the armed forces. Then the official of the General Staff told me that the missions of communication for security and defense were to coordinate the forces, gather information, and create intelligence. It was also involved with social communication, or public relations, with the primary objective of informing the civilians about the role of the armed forces in peacetime, with the appropriate compartmentalization of information under high command supervision.

The official clearly (and correctly) referred to some of the missions of the strategic dimension of communication and the intelligence process, and then to the activities of social communication and public relations. But where is the strategy that the journalist told me about? Nowhere, of course. What she called "strategic communication" is nothing more than public relations based on social communication. Why is this not strategic? Because this type of communication neither works in the strategic dimension nor pursues any vital objective of the nation-state. Strategy focuses attention on how to articulate the tools for achieving goals related to dealing with threats that lead to conflicts, and furthermore, it recognizes that the means employed must be coordinated at the highest level of the nation-state and must also understand the broad spectrum of all the resources that constitute national power. Or, as Professor Harry Yarger said in his definition of strategy and its objectives (state interests): "Strategy is all about how (way or concept) leadership will use the power (means or resources) available to the state to exercise control over sets of circumstances and geographic locations to achieve objectives (ends) that support state interests. Strategy provides direction for the coercive or persuasive use of this power to achieve specified objectives" 8

The discussion that I related above ended when the journalist began to refer to "the operative strategy" and "the tactical strategy." In that moment, the official of the General Staff and I looked at each other and decided to gently end the discussion and to assent to what the journalist said. But it caught my attention that a journalist in charge of the area of social communication of a defense agency so flagrantly confused the strategic, operative, and tactical dimensions, mixing them without any shame. Two years after that, when I was again in the United States, I had a conversation with an accomplished professional in the national defense sector who said that, while it could not be

8 H. Richard Yarger, "Towards a Theory of Strategy: Art Lykke and the Army War College Strategy Model” (Carlisle: U.S. Army War College, 2008); available at www.au.af.mil/ au/awc/awcgate/army-usawc/stratpap.htm. 


\section{THE QUARTERLY JOURNAL}

referred to as "strategic communication," since it was a process that was still a subject of study that was only being discussed, the mission of social communication in the area of defense was to facilitate communication with the media; this person also spoke of public relations, which had the mission to gain trust, understanding, and support from the public. Therefore, social communication is confused with strategic communication merely due to the fact that the concept or word "strategy" reflects the importance of the role that civilians play in security and national defense.

Later that same year, in a class of "Communication and Strategy for Crisis Simulation Games" for the high command course in Political and Strategic Studies at an academic institution in America, where I was guest lecturer in June 2008, the state officials who were the students in this course asked the following questions: What is strategic about strategic communication? What is the real field of action of strategic communication? Does it belong to business, marketing, advertising, journalism, defense, the state, or is it integrated into all of them? Is there an official, aligned and structured definition of strategic communication for security and national defense? What are the tools that strategic communication uses? What is the mission of strategic communication? Does it have to do with the press releases of the armed forces or the agencies and ministries of defense? Does it have to do with the internal communication of the institutions linked to the area of defense? Is it military diplomacy? Or it is coercive diplomacy? Or perhaps it has to do with telecommunications and communicational coordination of the forces? Without doubt, there are many questions about strategic communication, but so far there seems to be only one answer: The definition of strategic communication is lost in a universe full of ambiguities, confusions, and conceptual gaps.

However, does this mean that it is impossible to know what strategic communication is, what its qualities and missions are? These statements make the use of communications as a vital tool evident, but when we are talking about strategic communication we attribute it to many disciplines and pseudo-disciplines, thus creating confusion that prevents us from understanding and working with this instrument. Hence, this article is based on the results of an interdisciplinary approach between Strategic Studies and Mass Communication in the field of security and national defense. As was stated above, it attempts to provide a definition, missions, and lineaments for strategic communications, and creates a model proposal for "Strategic Communication for Security and National Defense," with the objective of tracing the guidelines of this vital tool for pursuing and maintaining permanent national objectives, including peacekeeping.

\section{Methods}

It needs to be mentioned that this article aims to deliver to professionals in the academic and political-military area, simply and clearly, the results of a hermeneutic qualitative-quantitative research study through an interdisciplinary approach between the "models of strategy" of Beaufre $(1965)$ " and the "models of communication" of

\footnotetext{
9 Andre Beaufre, “An Introduction to Strategy” (New York: F. Praeger, 1965).
} 
Laswell (1948) ${ }^{10}$, Berlo (1960) ${ }^{11}$, Schramm (1954) ${ }^{12}$, Shannon $(1948)^{13}$ and Maletzke (1963) ${ }^{14}$ models selected by results of a selection criteria matrix. These have been integrated into the definitions of "National Security Strategy" and "National Defense Strategy" by analytical instruments designed for this research in order to identify and justify pertinent concepts and develop proposals for the definition, lineaments, missions and model of strategic communication for security and national defense.

Design

This research created five instruments using hermeneutic, qualitative, and quantitative methods for the interdisciplinary approach by analyzing the objects of study and the inductive codes (see Table 1).

Table 1: Study Instruments.

\begin{tabular}{|l|l|}
\hline $\mathbf{1}$ & Instruments \\
\hline SCA & Selection criteria analysis \\
$H A M$ & Hermeneutic analysis matrix \\
Q-QAM & Qualitative-quantitative analysis matrix \\
HDM & Hermeneutic definition matrix \\
IHDM & Integral hermeneutic definition matrix (interdisciplinary approach) \\
\hline $\mathbf{2}$ & Objects of study \\
\hline M.S & Models of Strategy of Beaufre (1975) \\
M.C & Models of Communication of Laswell (1948), Berlo (1960), Schramm \\
D.NSS & (1954), Shannon (1948) and Maletzke (1963) \\
D.NDS & Definition of National Security Strategy of DoD \\
\hline $\mathbf{3}$ & Definition of National Defense Strategy of DoD \\
\hline C.S & Inductive codes \\
C.C & Concepts of Strategy \\
C.SND & Concepts of Communication \\
\hline
\end{tabular}

10 Harold D. Lasswell, "The Structure and Function of Communication in Society," in Lyman Bryson, ed., The Communication of Ideas (New York: Harper \& Bros., 1948).

11 David K. Berlo, The Process of Communication (New York: Holt, Rinehart, \& Winston, 1960).

12 Wilbur Schramm, The Process and Effects of Mass Communication (Urbana: University of Illinois Press, 1954).

13 Claude E. Shannon, A Mathematical Theory of Communication (New York: Bell System Technical Journal, 1948).

14 Gerhard Maletzke, Psychologie der Massenkommunikation; Theorie und Systematik (Hamburg: Hans Bredow-Institut, 1963). 


\section{Thesis}

The definition, lineaments, missions, and model of strategic communication for security and national defense should integrate the concepts of strategy, concepts of communication, and concepts of national security and defense in order to communicate strategically and achieve the national objectives and national interest of a nation-state.

\section{Specific Objectives}

In addition to the general objectives outlined above, this study has several specific objectives:

1. To identify the relevant concepts of strategy (C.S) by analyzing the models of strategy (M.S) of Beaufre using a hermeneutic analysis matrix (HAM).

2. To identify the relevant concepts of communication (C.C) by analyzing the models of communication (M.C) of Laswell (1948), Berlo (1960), Schramm (1954), Shannon (1948), and Maletzke (1963) using a hermeneutic analysis matrix.

3. To identify the relevant concepts of security and national defense (C.SND) by analyzing the definitions of "National Security Strategy" and "National Defense Strategy" employed by the U.S. Department of Defense using a hermeneutic analysis matrix.

4. To verify the relevant model of strategy for the interdisciplinary approach by using a qualitative-quantitative analysis matrix (Q-QAM) of the models of strategy and concepts of communication.

5. To verify the relevant model of communication for the interdisciplinary approach by using a qualitative-quantitative analysis matrix of the models of communication and concepts of strategy.

6. To develop a definition of strategy based on the results of the hermeneutic definition matrix (HDM) of concepts of strategy and concepts of security and national defense.

7. To develop a definition of communication based on the results of the hermeneutic definition matrix of concepts of communication and concepts of security and national defense.

8. To develop a definition of strategic communication for security and national defense based on the results of the integral hermeneutic definition matrix (IHDM) of concepts of strategy, concepts of communication, and concepts of security and national defense.

9. To explore the lineaments of strategic communication for security and national defense based on the results of the hermeneutic analysis matrix.

10. To explore the missions of strategic communication for security and national defense based on the results of the hermeneutic analysis matrix.

11. To design and propose a model of strategic communication for security and national defense as final result of this research. 


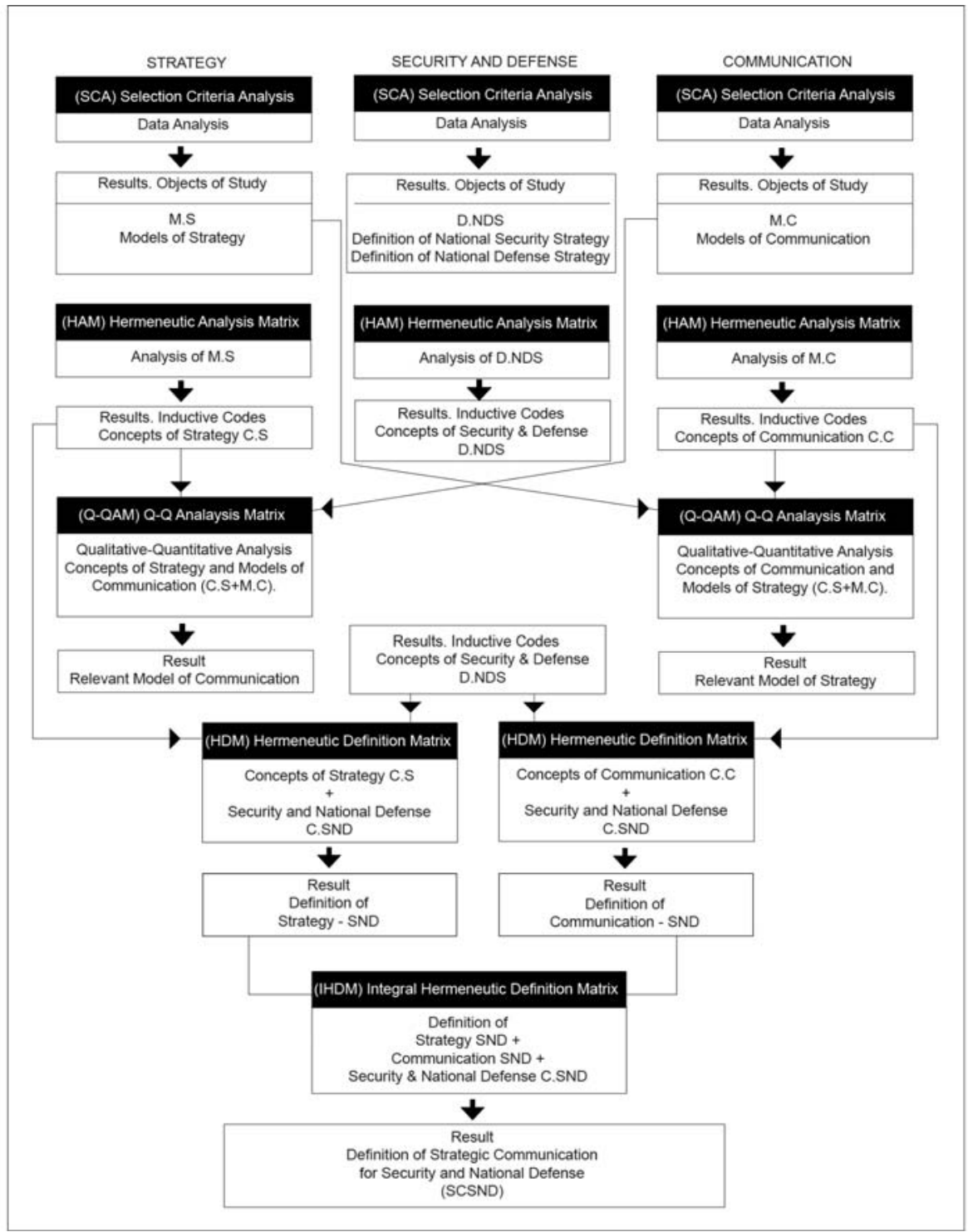

Figure 1: Research Process of Definition. ${ }^{15}$

15 This figure shows the instruments of: Selection Criteria Analysis; Hermeneutic Analysis Matrix; Qualitative-Quantitative Analysis Matrix; Hermeneutic Definition Matrix; and Integral Hermeneutic Definition Matrix. 


\section{Process}

The process of this research was divided into eight phases:

1. Selection criteria analysis (SCA) of models of strategy and models of communication and definitions of "National Security Strategy" and "National Defense Strategy."

2. Hermeneutic analysis matrix of models of strategy and models of communication and definitions of "National Security Strategy" and "National Defense Strategy."

3. Qualitative-quantitative analysis matrix of models of strategy and models of communication and definitions of "National Security Strategy" and "National Defense Strategy."

4. Hermeneutic definition matrix of concepts of strategy and concepts of security and national defense.

5. Hermeneutic definition matrix of concepts of communication and concepts of security and national defense.

6. Integral hermeneutic definition matrix of definitions of strategy, communication, and security and defense.

7. Hermeneutic analysis matrix of the relevant model of strategy, the relevant model of communication, and the definition of strategic communication for security and national defense created in this research.

8. Design and propose a model for strategic communication for security and national defense.

\section{Results}

According to the instruments of this research (selection criteria analysis, hermeneutic analysis matrix, qualitative-quantitative analysis matrix, hermeneutic definition matrix, and the Integral hermeneutic definition matrix), this research approves the thesis with the following results.

\section{Selection Criteria}

- Results of the selection criteria analysis (models of strategy). The models of strategy (object of study) in this research are: Beaufre's models; direct threat model; indirect pressure model; total vs low military intensity model; successive action model; and violent military victory model.

- Results of the selection criteria analysis (models of communication). The models of communication (object of study) in this research are: Laswell's model; Berlo's model; Schramm's model; Shannon's model; and Maletzke's model (see Figures 2 and 3). 
Figure 2: Selection Criteria (Models of Strategy). ${ }^{16}$

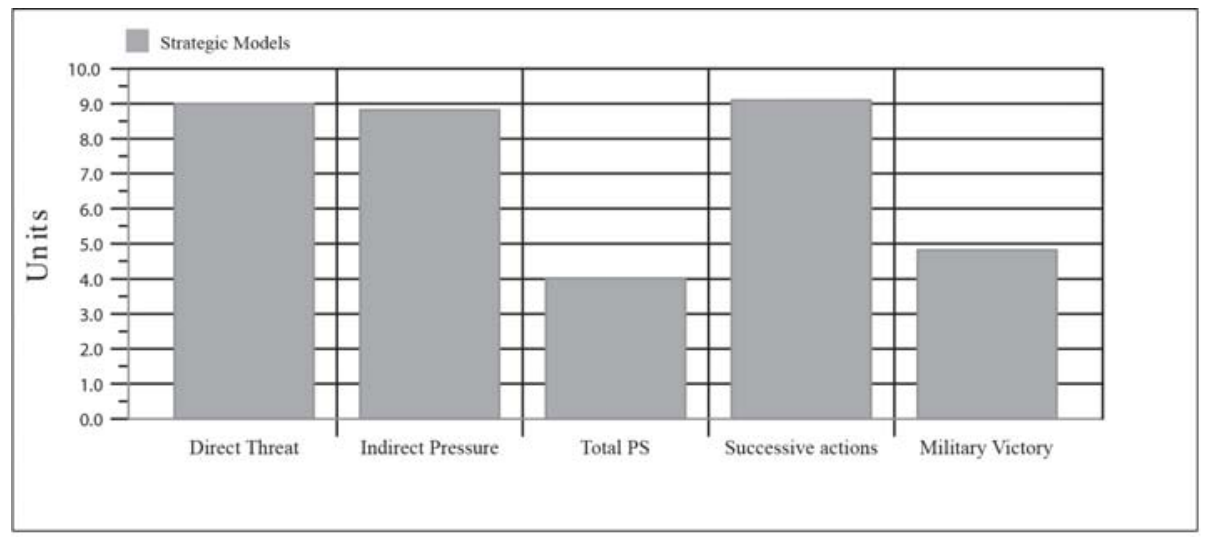

$\sum f_{10}^{0.100}[M . S+C . C]+$ SuccAct, $M=9.10$

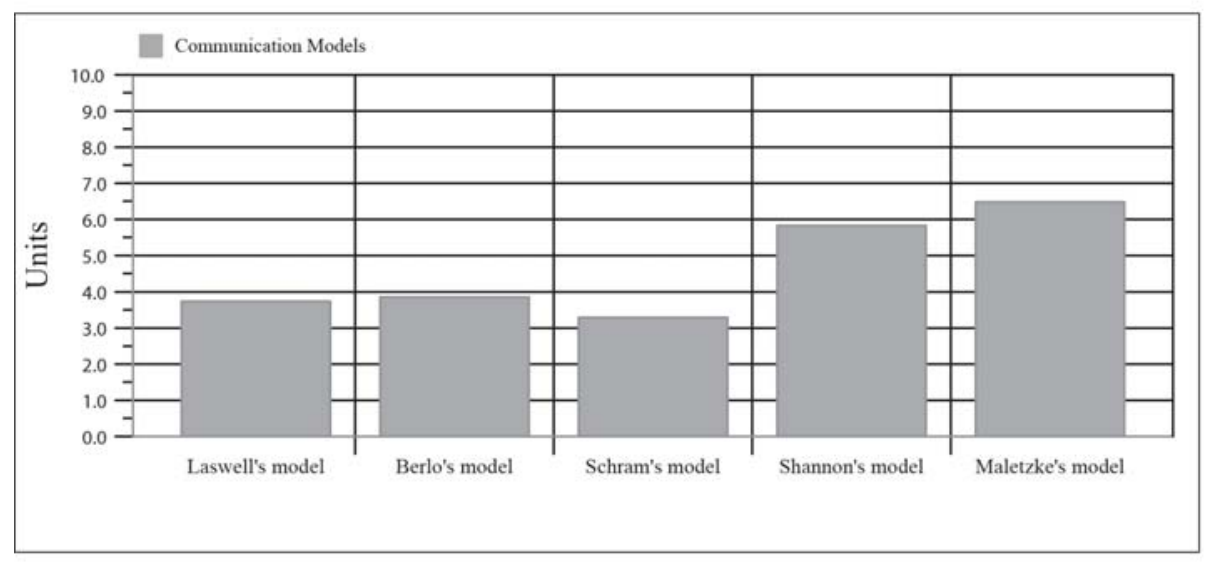

$\sum f_{10}^{0.100}[$ M.C $+C . S]=$ Maletzke, $M=6.486$

Figure 3: Selection Criteria (Models of Communication). ${ }^{17}$

16 Relevant Model of Strategy; Successive Actions*= SuccAct, M.

17 Relevant Model of Communication; Maletzke*= Maletzke, M. 


\section{Inductive Codes}

- Results of hermeneutic analysis matrix (concepts of strategy). The relevant concepts of strategy are: national objectives, national interests, national power, strategic dimension, instruments coordination, dissuasion, freedom of action, and legitimacy.

- Results of hermeneutic analysis matrix (concepts of communication). The relevant concepts of communication are: key message, media coordination, information flow, perception, persuasion, stimulus, reaction, and effect.

- Results of hermeneutic analysis matrix (concepts of security and national defense). The relevant concepts of security and national defense are: national power, defense, strategic objectives, armed forces, security, intelligence, national interest, coordination of instruments, peace, conflict, and war.

\section{Qualitative-Quantitative Analysis}

\section{Results of Qualitative-Quantitative Analysis (Concepts of Strategy and Mod- els of Communication)}

The qualitative-quantitative analysis of concepts of strategy (national objectives, national interests, national power, strategic dimension, instruments coordination, dissuasion, freedom of action, and legitimacy) and models of communication is equal to the integration of the concepts of (C.S) + (M.C), which shows as a result that the pertinent model of communication to integrate in this interdisciplinary approach is the model of communication of Maletzke (method based on sender, message, transmission, noise, channel, reception, receiver, and feedback).

The formula in the result explains: The sum of the analysis formula 0.100/10 (set of models of communication and concepts of strategy) equals the model of Maletzke (total of 6.486). (See Table 2)

\section{Results of Qualitative-Quantitative Analysis (Concepts of Communication and Models of Strategy)}

The qualitative-quantitative analysis of concepts of communication and models of strategy is equal to the integration of (C.C) + (M.S), which shows as a result that the pertinent model of strategy to integrate in this interdisciplinary approach is Beaufre's "successive actions" model of strategy (method based on coordinated and successive action of the "direct threat" and "indirect pressure" models).

The formula in the result explains: The sum of the analysis formula 0.100/10 (set of models of strategy and concepts of communication) equals the model of successive actions (total of 9.10) (see Table 3). 
SPRING 2013

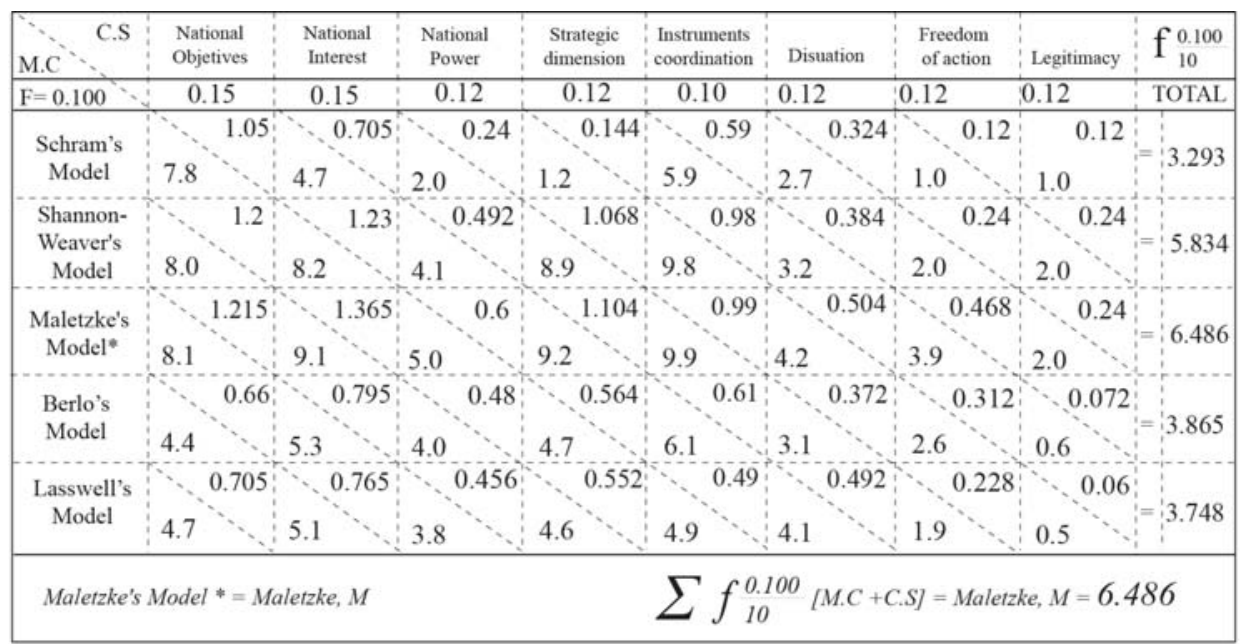

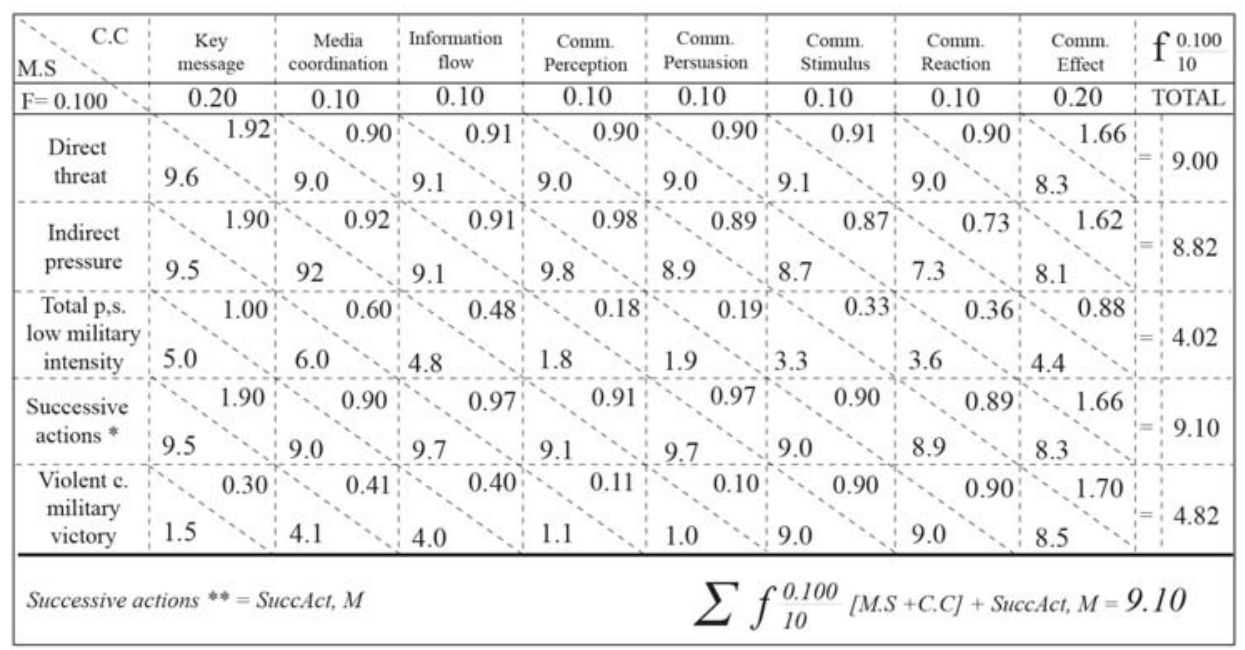

Table 2. Concepts of Strategy and Models of Communication. 


\section{THE QUARTERLY JOURNAL}

\begin{tabular}{|c|c|c|c|c|c|c|c|c|c|}
\hline M.C C.S & $\begin{array}{c}\text { National } \\
\text { Objetives }\end{array}$ & $\begin{array}{l}\text { National } \\
\text { Interest }\end{array}$ & $\begin{array}{c}\text { National } \\
\text { Power }\end{array}$ & $\begin{array}{c}\text { Strategic } \\
\text { dimension }\end{array}$ & $\begin{array}{l}\text { Instruments } \\
\text { coordination }\end{array}$ & Disuation & $\begin{array}{c}\text { Freedom } \\
\text { of action }\end{array}$ & Legitimacy & $\mathrm{f}_{10}^{0.100}$ \\
\hline $\mathrm{F}=0.100$ & 0.15 & 0.15 & 0.12 & 0.12 & 0.10 & 0.12 & 0.12 & 0.12 & TOTAL \\
\hline $\begin{array}{l}\text { Schram's } \\
\text { Model }\end{array}$ & & 4.7 & 2.0 & 1.2 & & 2.7 & 1.0 & $1.0^{0.12}$ & $=3.2$ \\
\hline $\begin{array}{c}\text { Shannon- } \\
\text { Weaver's } \\
\text { Model }\end{array}$ & 8.0 & 8.2 & 4.1 & 8.9 & 9.8 & $\begin{array}{l} \\
3.2\end{array}$ & 2.0 & & 5.834 \\
\hline $\begin{array}{l}\text { Maletzke's } \\
\text { Model* }^{*}\end{array}$ & 8.1 & 9.1 & 5.0 & 9.2 & 9.9 & 4.2 & & 2.0 & 6.4 \\
\hline $\begin{array}{l}\text { Berlo's } \\
\text { Model }\end{array}$ & & 5.3 & & & & & 2.6 & 0.6 & \\
\hline $\begin{array}{l}\text { Lasswell's } \\
\text { Model }\end{array}$ & 4.7 & 5.1 & & & & 4.1 & 1.9 & $\begin{array}{l}0.06 \\
0.5\end{array}$ & \\
\hline Maletzke & del & ke, $M$ & & & $\sum f$ & 00 & S] & $e, M$ & \\
\hline
\end{tabular}

\begin{tabular}{|c|c|c|c|c|c|c|c|c|c|}
\hline M.S C.C & $\begin{array}{c}\text { Key } \\
\text { message }\end{array}$ & $\begin{array}{c}\text { Media } \\
\text { coordination }\end{array}$ & $\begin{array}{l}\text { Information } \\
\text { flow }\end{array}$ & $\begin{array}{c}\text { Comm. } \\
\text { Perception }\end{array}$ & $\begin{array}{c}\text { Comm. } \\
\text { Persuasion }\end{array}$ & $\begin{array}{l}\text { Comm. } \\
\text { Stimulus }\end{array}$ & $\begin{array}{c}\text { Comm. } \\
\text { Reaction }\end{array}$ & $\begin{array}{l}\text { Comm. } \\
\text { Effect }\end{array}$ & $\mathrm{f}_{10}^{0.100}$ \\
\hline $\mathrm{F}=0.100$ & 0.20 & 0.10 & 0.10 & 0.10 & 0.10 & 0.10 & 0.10 & 0.20 & TOTAL \\
\hline $\begin{array}{l}\text { Direct } \\
\text { threat }\end{array}$ & & 9.0 & .1 & 9.0 & & & 9.0 & & 9.00 \\
\hline $\begin{array}{l}\text { Indirect } \\
\text { pressure }\end{array}$ & & 92 & & & & & 73 & & 8.82 \\
\hline $\begin{array}{l}\text { Total p,s. } \\
\text { low military } \\
\text { intensity }\end{array}$ & 5.0 & 6.0 & 4.8 & 1.8 & 1.9 & .3 & 3.6 & 0.88 & 4.02 \\
\hline $\begin{array}{c}\text { Successive } \\
\text { actions * }\end{array}$ & & & & & & 9( & & $\because 1.60$ & 9.10 \\
\hline $\begin{array}{l}\text { Violent } \mathrm{c} . \\
\text { military } \\
\text { victory }\end{array}$ & 1.5 & 4.1 & 4.0 & 1.1 & & .0 & & 8.5 & 4. \\
\hline Succes & & $M$ & & & & 100 & & & .10 \\
\hline
\end{tabular}

Table 3. Concepts of Communication and Models of Strategy. 


\section{Results of the Hermeneutic Definition Matrix (Communication - Security and National Defense)}

The result of the hermeneutic definition matrix of communication in the area of security and national defense in this research is: Communication in the area of security and national defense is the significant message constructed by concepts targeted across a coordinated platform of pertinent media (traditional and non-traditional) so that they can be received by a social collectivity or an entity as a whole, considering scenario factors, direct and indirect actors and thus positioning an image-message and perception in a target group(s) supporting the security and defense objectives of the nationstate. The formula is:

$$
C+S D=(\text { Inf,Int,Decl,Cod1,Sig1,Plt,Dif })=\text { Communication }=\left(C^{*}\right)^{18}
$$

\section{Results of the Hermeneutic Definition Matrix (Strategy - Security and Na- tional Defense)}

The result of the hermeneutic definition matrix of strategy in the area of security and national defense in this research is: Strategy in the area of security and national defense is a science and art that searches through coordinated action logics for a political-strategic decision to serve as the solution to a problem or potential problem, using and coordinating the tools and resources of national power, which were made available in a particular scenario where there are conflicts of interests between two or more actors in order to achieve the national interest. The formula is:

$$
S+S D=(S P . m+I N P+N I)=\text { Strategy }=\left(S^{*}\right)^{19}
$$

\section{Results of the Integral Hermeneutic Definition Matrix (Strategic Communica- tion - Security and National Defense)}

According to the integral hermeneutic definition matrix of strategic communication for security and national defense, the inductive codes are:

1. Communication: key message, media coordination, information flow, perception, persuasion, stimulus, reaction, and effect. $C+S D=($ Inf,Int,Dec1,Cod1,Sig1,Plt,Dif $)=$ Communication $=\left(C^{*}\right)$

2. Strategy: national objectives, national interest, national power, strategic dimension, instruments coordination, dissuasion, freedom of action, and legitimacy.

$$
S+S D=(S P . m+I N P+N I)=\text { Strategy }=\left(S^{*}\right)
$$

${ }^{18} \mathrm{C}+$ SD: communication plus security and national defense; (Inf,Int,Dec1,Cod1,Sig1,Plt,Dif): information, intelligence, decodification, codification, significant message, platforms, diffusion; $\mathrm{C}^{*}$ : communication.

19 S+SD: strategy + security and national defense; (SP.m+INP+NI): strategic-political management plus instruments of national power plus national interest; $\mathrm{S}^{*}$ : strategy. 
3. Security and national defense: national power, defense, strategic objectives, armed forces, security, intelligence, national interest, coordination of instruments, peace, conflict, war, and international system.

[IS,Sec,Def]

If communication in the area of security and national defense is:

$C+S D=($ Inf,Int,Dec 1,Cod1,Sigl,Plt,Dif $)=$ Communication $=\left(C^{*}\right)$, and strategy in the area of security and national defense is: $S+S D=(S P . m+I N P+N I)=$ Strategy $=$ $\left(S^{*}\right)$, the sum of those gives us the following result:

$$
\begin{aligned}
& C+S D=(\text { Inf, Int }, \text { Dec 1,Cod1,Sig1,Plt,Dif })=\text { Communication }=\left(C^{*}\right)+ \\
& S+S D=(S P . m+I N P+N I)=\text { Strategy }=\left(S^{*}\right)=
\end{aligned}
$$$$
\text { Strategic Communication }=(S C)
$$

Therefore, when we integrate the results of communication $=(C *)$, strategy $=\left(S^{*}\right)$, and [IS,Sec,Def] in the equation, the result is:

$$
\begin{aligned}
& C+S D=(I n f, \text { Int,Dec1,Cod1,Sig1,Plt,Dif })=\text { Communication }=\left(C^{*}\right)+ \\
& S+S D=(S P . m+I N P+N I)=\text { Strategy }=\left(S^{*}\right)+[\text { IS,Sec,Def }]=\text { S.C.S.N.D }
\end{aligned}
$$

According to the integral hermeneutic definition matrix, the definition of strategic communication for security and national defense is as follows:

It is the political-strategic management of communication for the security and national defense of a nation-state that searches, analyzes, plans, coordinates, and activates the relevant resources through significant "action logics" (communication action courses) with a significant message constructed according to concepts targeted across a coordinated pertinent platform of media (traditional and non-traditional) in order to achieve a vital objective as solution to a communication problem in a particular scenario (war, crisis, or peace) where there are conflicting wills between other nationstates that interpose with the permanent objectives and/or national interests of one's own nation.

\section{Results of Hermeneutic Analysis Matrix (Lineaments of Strategic Communi- cation for Security and National Defense)}

According to the hermeneutic analysis matrix, strategic communication for security and national defense should participate in the fields of action and support the national strategy through communication to achieve the political-strategic objectives. Consequently, a nation-state has a security and national defense policy with which it activates by means of the fields of action (internal, external, economic, and defense) the mission of achieving and protecting the national interests under pressure and threats.

Therefore, the four fields of action work on the mission of achieving national objectives under pressure and threats, but it is the responsibility of strategic communication to achieve internal and external legitimacy for the action. By obtaining this, the legitimacy of the international system is achieved, and with it freedom of action. 
In conclusion, the lineaments of strategic communication for security and national defense are:

- Pursuing the national interests and the political-strategic objectives of the nation-state

- Working in the political-strategic dimension.

Results of Hermeneutic Analysis Matrix (Mission of Strategic Communication for Security and National Defense)

According to the hermeneutic analysis matrix, the nucleus of the mission of strategic communication for security and national defense is to support the national security strategy and national defense strategy (national strategy) by contributing to maintaining, protecting, and achieving the national interests and objectives of the nation-state.

The mission of strategic communication for security and national defense is divided by temporary states (peace, crisis, and conflict):

- In times of peace, to achieve deterrence in the hemisphere and strategic stature in the international system

- In a state of crisis, to obtain credibility in the international system

- In a state of war, to achieve internal and external legitimacy in the international system in order to obtain freedom of action.

\section{Model Proposal for Strategic Communication for Security and National Defense}

The proposed model of strategic communication for security and national defense integrates the observation and analysis of the scenario called "source of information," where the direct and indirect players and the internal and external target groups (the target groups are the social masses) interact at the point where the conflict of interests is detected. Then the intelligence process develops and decodes useful information (decoding process 1), which is the knowledge required to actualize the pertinent strategic communication from the transmitter entity, which encodes the messages (encoding process 1) and projects them through a platform of media to the social media that decode the information (decoding process 2) and sends it to the target groups, which in turn decode the information (decoding process 3 ) a second time, creating the perception within the international system.

This international system perception is what the strategic communication process uses to achieve credibility, legitimacy, and therefore deterrence and freedom of action, which are vital to support the national strategy and to protect, restore, maintain, and achieve the permanent national objectives and national interests.

\section{Elements of Strategic Communication for Security and National Defense}

Communication Scenario. The communication scenario is the scenario of the international system, in which the following are identified: the conflict of interests, our global 


\section{THE QUARTERLY JOURNAL}

situation, the direct and indirect actors, the internal and external targets, the sources of information, as well as the intervening factors. The international system scenario is the universe of knowledge of the intelligence process, and the intelligence cycle sends the "useful information" to the transmitter who designs the strategic communication.

Conflict of Interests. On the basis of the permanent interests of nation-states, the conflict of interest is the neuralgic point of international relations. The conflict of interests occurs when a nation-state sees its permanent interests threatened by an intention or action of another actor or actors in the international scenario or when two actors have the same interest, leading to a dispute of interests and therefore to a probability of conflict and likely escalation of crisis.

Source of Information. This is the international system divided by: the national information source, the local information source, hemispheric information source, continental information source, supra continental information source, and worldwide information source. The sources of information are the universe of knowledge that uses intelligence to develop useful information for the strategic communication of our nationstate.

Intervening Factors. These are factors that intervene in the communication process that are beyond the control of the actors, and which arise only in the scenario of the international system - for example, natural disasters, political assassinations, or other unexpected events.

Intelligence Process or Intelligence Cycle. This is the process of analyzing the information and transforming it into useful information for the strategic communication process. That can come from open or closed sources of information. It also is the first decoding process.

1. Planning: This is the process through which intelligence requirements, priorities, the methodology to be employed, and the system that will search for information are determined.

2. Search and collection: This phase involves the search for and exploitation of sources of information, whether they are open or closed. The open sources are accessible to the public, while closed sources are those that are confidential or for non-public use.

3. Processing, analysis, and production of information: This is the analysis process of the information obtained by open and closed sources whose methodology allows that information to be transformed into intelligence (useful information).

4. Diffusion: This is the step in which the intelligence process delivers useful information to the transmitter entity depending on the strategy for security and national defense, which then guides the analysis and produces a new intelligence requirement, which activates the intelligence cycle anew.

Transmitter Entity. This is the entity formed by the agencies or offices in charge of strategic communication for security and national defense. It is the entity that creates 
the strategic communication with the media at the disposal of the nation-state, obtains useful information through the intelligence processes, and encodes, plans, coordinates, and distributes the key messages.

Key Message. This is part of the first encoding process, which through a process of analysis and strategic planning creates the vital idea to be positioned in the international system's perception designed by the transmitter entity with the purpose of supporting the national objectives and national interests of the nation-state. The key message changes depending on global situations and the missions of strategic communication:

- In times of peace: to achieve deterrence in the hemisphere and strategic stature in the international system

- In a state of crisis: to obtain credibility in the international system

- In a state of war: to achieve internal and external legitimacy in the international system in order to obtain freedom of action.

Action Logics. These are the logics of the execution procedure of strategic communication, coordinated with the courses of action in the strategic, operative, and tactical dimensions, all of which are synchronized with the key message in the transmitter entities, fields of action, and media platforms that are selected to transmit the key message. The action logics are the joint actions of strategic communication.

Transmitter Entities. These are the agencies, offices, or departments designated in the four fields of action that are coordinated by the transmitter entity. These transmitter entities comply with the diffusion mission of the key message through the selected media platforms.

Media Platforms. These are the channels carrying the key message. They are divided into traditional platforms (e.g., television, radio, newspapers, and others) and non-traditional communication platforms (e.g., Internet, online forums, discussion groups, emails, speeches, parades, contests, events, and others) and are part of the strategic communication planning.

Social Media. These are the communication media that have perception and selfauthority for emission and that are found within our nation-state, in the opponent nation-state, in indirect actors, and therefore in the international system. These media are divided into:

- Traditional social media (analog): News, television, books, articles, propaganda, newspapers, and radio

- Non-traditional social media (digital): Blogs, articles, forums, newsletters, social websites, as well as mobile applications in phones, computers, and many others 
THE QUARTERLY JOURNAL

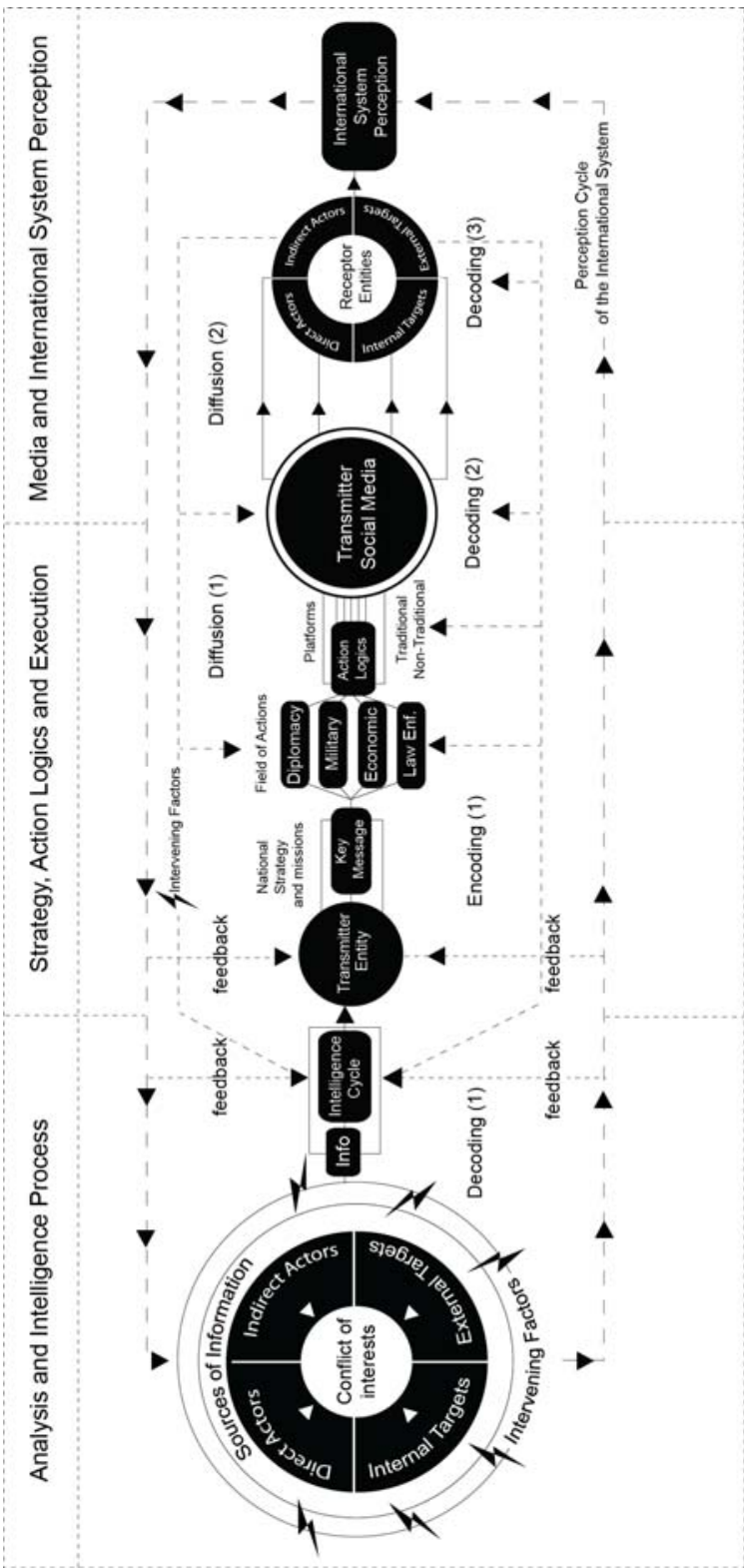

Figure 4: Model Proposal for Strategic Communication for Security and National Defense. $^{20}$

${ }^{20}$ Conflict of interest: (Info+Int), (Dec1,Cod1,Dif1), (Dec2,Dif2,Dec3) = ISP. 
- Activist social media (hybrid): They are those platforms that use traditional and non-traditional social media (analog and digital), including protests, news, speeches, parades, and many others.

Social media decode the transmitted message, and then transmit the message a second time with a new decoding process with intervening factors of the scenario.

Target Groups. These are divided into direct and indirect target groups, which are segments of the populace to whom the message is sent and who decode the message a second time, absorbing the conceptualizations targeted by the strategic communication effort.

Actors. These are divided into direct actors and indirect actors. Direct actors are those actors who interact directly with the problem of conflicts of interests (other nation-states or international organizations), and the indirect actors are those who are of importance even though they are not playing a leading role in the problem. It is these groups that create the international system perception.

International System's Perception is the set of target groups that is also under the influence of intervening factors and that receives and interprets messages through an idea or sensation that results in the material impression in opinions. These opinions create the perception, and these perceptions are those from which the credibility of the nation-states - and therefore their legitimacy and possible freedom of action-originates, activating the cycle of the international system perception.

This model is a proposal for the logical process of strategic communication for security and national defense based on the results obtained by the methodological integration of communication, strategy, and security and national defense using the hermeneutic-qualitative-quantitative research method (see Figure 4).

\section{Conclusions}

\section{About the Interdisciplinary Approach}

The integration of Beaufre's "successive actions" strategy model and Maletzke's model of communication with the definitions of "National Security Strategy" and "National Defense Strategy" was successfully achieved. This integration resulted in a clean and structured interdisciplinary approach that integrates the processes of strategy and communication, which were integrated under the lineaments, missions, and objectives of security and national defense (see Figure 5).

Subsequently, based on the five instruments of analysis that were designed as part of this research, the construction of the definitions of "strategy" and "communication" in the area of security and national defense, as well as the definition of "strategic communication for security and national defense," was achieved.

\section{About Strategy}

First, I need to say that strategy is a science and discipline that is unique among the political and military sciences. Strategy is always connected to the vital objectives and 


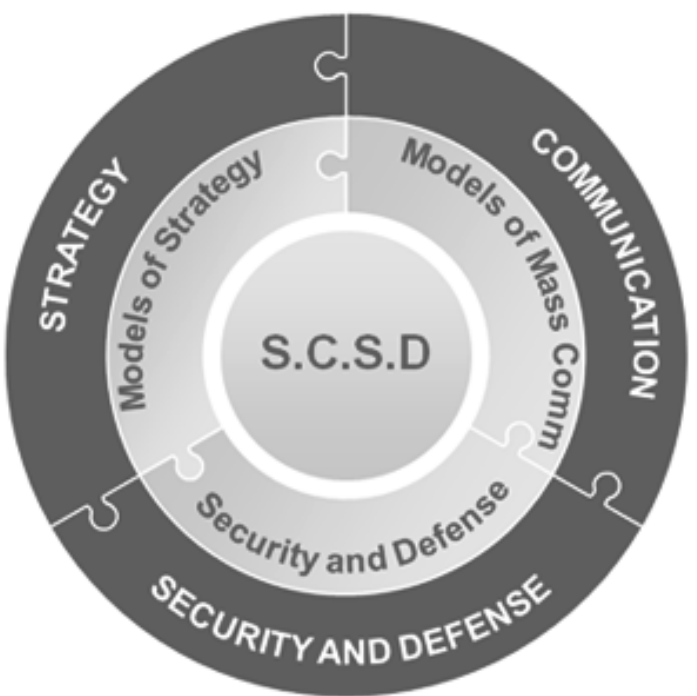

Figure 5: Interdisciplinary Approach.

interests of a nation-state. This has been the case from antiquity, with Thucydides and Xenophon, through to Clausewitz, Liddell Hart, Beaufre, and many other strategists.

Based on the selection criteria and qualitative research process, I can say with absolute certainty and clarity that a "real strategy process" is never found in the field of medicine, education, engineering, psychology, marketing, or any other discipline or pseudo-discipline. This is because they are not working with the resources or powers of the nation-state, and do not pursue national political-strategic objectives or national interests, and therefore are not vital for a nation-state.

Strategy in the area of security and national defense occurs only in the strategic or political-strategic dimensions of a nation-state. If the discipline, profession, pseudodiscipline, craft, or activity that wants to be called "strategic" does not lie within these dimensions, and its mission is not to support the political-strategic objectives of a nation-state, it is not strategic.

\section{About the Definition Problem of Strategy}

This hijacking of the concept results in clumsy rearrangements and clumsy rhetorical configurations that confuse tactics with maneuvers, maneuvers with operations, tactics with strategy, strategy with maneuvers, etc. Its use is purely decorative, intended to denote "smart thinking." Until today it has been used without limitation in any activity, almost as a surname, among which we find: strategic public relations, strategic social communication, strategic protocol, strategic marketing, strategic psychotherapy, strategic medicine, etc. In fact, I have found some that are even more aberrant than those indicated: strategic operations, strategic tactics, strategic therapy, strategic psychology, 
strategic massage, strategic engineering, strategic mathematics, strategic physiology, strategic philosophy, and a very peculiar one - strategic metaphysics.

The "professionals" working in these areas do not have any idea what "strategic" means. On the other hand, concept migration to other disciplines is acceptable, as long as the core significance of the concept is maintained. However, this research discovered, in the process of studying the problem, that with their drafts of the definition and roles of strategic communication, disciplines such as public relations, marketing, advertising, journalism, and many others have failed in their attempt to migrate the concept. They have also (while attempting to fulfill their roles working in the security and national defense area, confused management with planning, strategy with operation, and operation with tactics, along with many other atrocities.

\section{About Strategic Communication for Security and National Defense}

Up to this point, strategic communication in the area of security and national defense has been neither an instrument nor a method, a doctrine, nor a policy. It does not possess lineaments, missions, or roles, and does not pursue any clear objectives. It only has attempts at definitions, without any official study to substantiate them. This research has concluded that today, strategic communication in the area of security and national defense is nothing more than "a project idea" - a draft of definition without any theoretical or methodological basis, and a logical practice mired in a battlefield of disciplines and professions that intend to adopt the concept in one way or another without any attention to the intellectual consequences. They forget the significance of the strategy concept and unsuccessfully try to accommodate it, regardless of the mutilation of the lexicon.

\section{About Strategic Communication in Other Areas}

With full confidence in this research, and based on the obtained results I can say that strategic communication is not marketing, advertising, public relations, journalism, psychology, sociology, social communication, visual communication, anthropology nor any other area related to these. However, strategic communication should fulfill the role of selecting, leading, integrating, coordinating, activating, and executing the resources of these disciplines in order to support the national objectives and permanent interests of a nation-state.

Until now, many organizations have had their own definition of strategic communication, which is almost always a malformation of the strategy concept associated with any activity that plans a communication campaign (this is publicity in the case of private enterprises, and social communication in the case of public enterprises). It is noteworthy that journalists who are working in security and defense sector call informing the community about what the institution does "strategic communication," although it is actually more connected with public relations and social assistance. These are far removed from the strategic dimension and action fields of a nation-state, and so do not develop strategic communication, but rather only communicate socially. 


\section{About the Lineaments of Strategic Communication for Security and National Defense}

This research discovered in the qualitative-quantitative process that strategic communication must integrate the qualitative analysis instruments of mass communication and prospective decision-making and quantitative-probabilistic analysis tools of strategy. All of these must be structured with the "integral action logics," communication platforms, and "action courses" of the relevant actors of the scenario; the origin of the conflict; the odds, measures, and percentages; the courses of action; and the intervening factors in every stage of the scenario, as well as the behavior of the actors in the past, present, and future.

Therefore, strategic communication for security and national defense must have the lineaments of strategy:

- Pursuing the national interests and the political-strategic objectives of the nation-state

- Working in the political-strategic dimension.

\section{About the Missions of Strategic Communication for Security and National Defense}

Based on the qualitative analysis, the missions of strategic communication for security and national defense should support the national security strategy and national defense strategy by contributing to maintaining, protecting, and achieving the national interests and objectives of the nation-state, which are divided across different temporal periods (peace, crisis, war).

- In times of peace: to achieve deterrence in the hemisphere and strategic stature in the international system

- In a state of crisis: to obtain credibility in the international system

- In a state of war: to achieve internal and external legitimacy in the international system in order to obtain freedom of action.

In conclusion, through this research it has been possible to elucidate the definitions of what strategic communication for security and national defense is, what its missions and objectives are, and how it should act. It also provides a proposed model for strategic communication for security and national defense that was generated with the knowledge gained.

As a researcher, professional, and academic working in this field, I am very pleased with what has been explored and designed, since the exploratory study found that strategic communication for security and national defense aims, as part of its mission in supporting the national strategy, to achieve deterrence (dissuasion), legitimacy, and freedom of action in the international system. It is my personal objective to continue this research and proceed to a new stage in order to create a methodology and work system with a research proposal for a pertinent entity, university, or center of studies.

As the National Defense Authorization Act for Fiscal Year 2012 states: 
The committee also encourages the Department of Defense to continue to pursue workforce development opportunities that bring together diverse skill sets and career specialties. For example, the Department should do more to integrate social science skills, cultural intelligence, and human terrain understanding to the IO and SC field. The committee also believes that as the Joint Chiefs of Staff evaluate joint SC and IO training and education curricula, it ensures that it maintains and sustains existing centers of excellence. $^{21}$

Strategic communication is undoubtedly a vital tool for a nation-state, one that supports the national strategy, aims to achieve and protect the political-strategic objectives and national interests, and above all maintains the peace. Finally, without strategy, we can only communicate. Only with strategy we can communicate strategically.

21 U.S. House of Representatives, "Report of the House Armed Services Committee on the National Defense Authorization Act for Fiscal Year 2012" (Washington, D.C., 12 December 2011); available at http://www.gpo.gov/fdsys/pkg/CRPT-112hrpt329/pdf/CRPT-112hrpt329pt1.pdf. 


\section{Bibliography}

Beaufre, Andre. An Introduction to Strategy. New York: F. Praeger, 1965.

Berlo, David K.. The Process of Communication. New York: Holt, Rinehar t\& Winston, 1960.

H. Yarger, Richard. Towards a Theory of Strategy: Art Lykke and the Army War College Strategy Model. Carlisle: U.S. Army War College, 2008.

Jones, Jeffrey B.. "Strategic Communication: A Mandate for the United States." Joint Force Quarterly, no. 39 (2005).

Lasswell, Harold D.. The Structure and Function of Communication in Society. New York: Harper \& Bros, 1948.

Maletzke, Gerhard. Psychologie der Massenkommunikation; Theorie und Systematik. Hamburg: Hans Bredow-Institut, 1963.

Schramm, Wilbur. The Process and Effects of Mass Communication. Urbana: University of Illinois Press, 1954.

Shannon, Claude E.. A Mathematical Theory of Communication. New York: Bell System Technical Journal, 1948. 